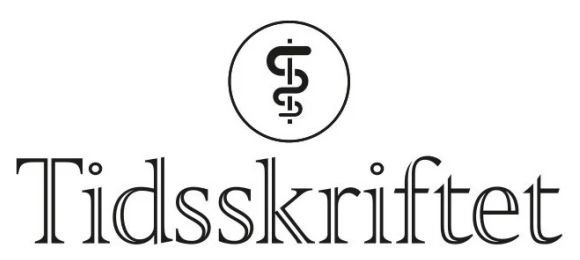

DEN NORSKE LEGEFORENING

\title{
Osteomyelitt i underkjeven
}

\author{
KORT KASUISTIKK
}

\section{ANJA NILSEN NYLAND}

Kjevekirurgisk avdeling

Haukeland universitetssjukehus

og

Institutt for klinisk odontologi

Universitetet i Bergen

Anja Nilsen Nyland er tannlege i spesialisering.

Forfatteren har fylt ut ICMJE-skjemaet og oppgir ingen interessekonflikter.

\section{ELIN SERINE NORDTVEIT}

Barne- og ungdomsklinikken

Haukeland universitetssjukehus

Elin Serine Nordtveit er lege i spesialisering.

Forfatteren har fylt ut ICMJE-skjemaet og oppgir ingen interessekonflikter.

\section{FRANZISKUS JOHANNES BOSSE}

Barne- og ungdomsklinikken

Haukeland universitetssjukehus

Franziskus Johannes Bosse er overlege.

Forfatteren har fylt ut ICMJE-skjemaet og oppgir ingen interessekonflikter.

\section{SIGBJØRN LØES}

loes@helse-bergen.no

Kjevekirurgisk avdeling

Haukeland universitetssjukehus

og

Institutt for klinisk odontologi

UiT Norges arktiske universitet

Sigbjørn Løes er avdelingssjef og professor.

Forfatteren har fylt ut ICMJE-skjemaet og oppgir ingen interessekonflikter.

Hevelser og smerter i kjeven er ofte assosiert med infeksiøs odontogen sykdom og vil typisk diagnostiseres og behandles hos tannlege. I noen tilfeller kan imidlertid ikke tanninfeksjoner påvises. Vi presenterer fire sykehistorier hos barn som illustrerer ulike utfordringer ved en velkjent, men relativt dårlig definert diagnose i medisinen.

\section{Pasient 1}


En tidligere frisk gutt i barneskolealder ble henvist til kjevekirurgisk avdeling på grunn av smerter, hevelse og rødhet i venstre underkjeve samt rødhet bak øret på samme side.

Pasienten hadde redusert gapeevne, men ikke vekttap eller feber. Han var tidligere plaget med hyppige halsinfeksjoner.

Det ble ikke avdekket tannpatologi ved klinisk undersøkelse, tannrøntgen eller dental panoramarøntgen (ortopantogram, OPG). Antibiotikabehandling med fenoksymetylpenicillin-mikstur $50 \mathrm{mg} / \mathrm{mL} \times 3(7,5 \mathrm{~mL}+7,5 \mathrm{~mL}+15 \mathrm{~mL})$ ga tilbakegang av symptomene i løpet av få dager. Nevnte ortopantogram, CT og MR av ansiktsknokler viste omfattende osteolytiske og inflammatoriske lesjoner i venstre underkjeve (figur 1). For å utelukke neoplasi ble det foretatt PET-CT-undersøkelse med fluorodeoksyglukose (FDG), som viste diffust $ø$ kt FDG-opptak i venstre ramus mandibula.

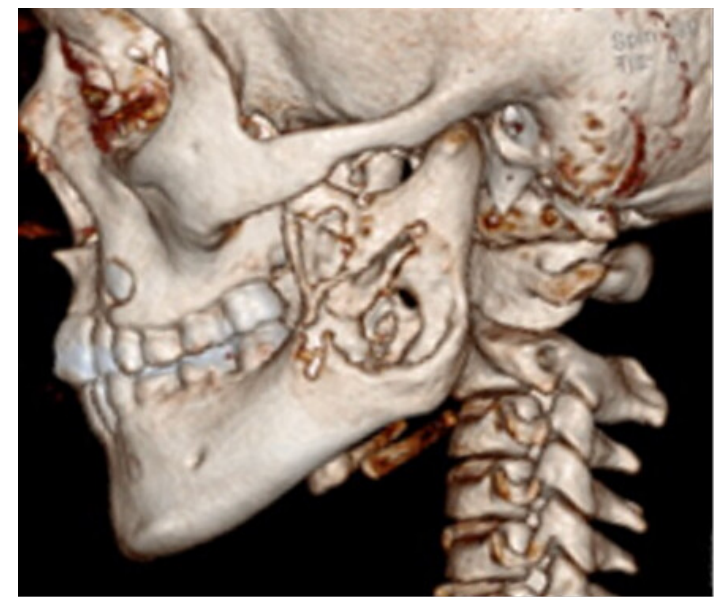

a

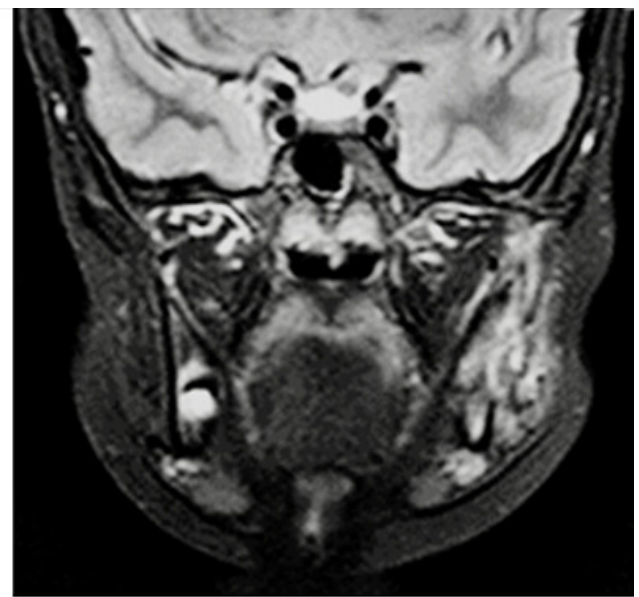

b

Figur 1 Pasient 1. a) 3D-rekonstruksjon etter CT viser omfattende destruksjon av venstre ramus mandibula. b) Inflammatoriske forandringer på samme side er tydelige på MR med kontrastvæske (koronalsnitt).

To måneder etter symptomdebut ble det tatt biopsi i generell anestesi med trepanbor transoralt. Det ble ikke observert inflammasjon i omliggende bløtvev, men hele ramus mandibula var ekspandert. Histologisk snitt viste ben med reaktive forandringer forenlige med sent stadium i en behandlet osteomyelitt uten tegn til malignitet. Bakterieprøver ga rikelig vekst av Streptococcus mitis, middels vekst av apatogen Neisseria og sparsom vekst av Staphylococcus epidermidis.

Pasienten fortsatte med fenoksymetylpenicillin, og én måned senere ble det utført kirurgisk dekortikering av underkjeven og fjerning av sekvestre med transoral tilgang. Det ble funnet betydelige mengder løst nekrotisk ben uten tegn til pussdannelse. Ny bakterieprøve ga rikelig vekst av Actinomyces odontolyticus, streptokokker i mitis/oralisgruppen og Actinomyces sp., og sparsom vekst av Neisseria sp. og Rothia mucilaginosa. Antibiotikabehandlingen ble endret til klindamycin $10 \mathrm{mg} / \mathrm{kg} \times 3$ i ytterligere to måneder. Ved senere kliniske kontroller var det fine forhold, avtagende asymmetri og god gapeevne.

\section{Pasient 2}

En tidligere frisk jente i barneskolealder ble henvist fra offentlig tannklinikk på grunn av vedvarende hevelse under venstre underkjeve. Tilstanden hadde vart i ti uker uten feber eller nedsatt allmenntilstand. Pasienten hadde initialt blitt behandlet med fenoksymetylpenicillin-mikstur $50 \mathrm{mg} / \mathrm{mL} \times 3(7,5 \mathrm{~mL}+7,5 \mathrm{~mL}+15 \mathrm{~mL})$ i to uker og etter et to måneders opphold i ytterligere fire uker med bedring av ubehag og gapebesvær. Hun var tidligere operert med dren grunnet residiverende ørebetennelser.

Det ble ikke funnet dental patologi verken ved klinisk undersøkelse, tannrøntgen, ortopantogram, MR eller CT. Det ble påvist asymmetrisk forstørret underkjeve på venstre side med benfortykkelse, sklerose og periostal reaksjon samt minimalt ødem i omgivende 
bløtvev. Funnet ble oppfattet som kronisk osteomyelitt.

Biopsi av underkjeven ble tatt med retromandibulær transkutan tilgang. Mikrobiologisk undersøkelse viste ingen oppvekst av aerobe eller anaerobe bakterier. Ved histologisk undersøkelse ble det funnet betennelsesceller, og forandringene ble oppfattet som forenlige med kronisk osteomyelitt. Pasienten fortsatte med fenoksymetylpenicillin i ni måneder (330 mg, 1 + 1 + 2 tabletter) og var symptomfri ved kontroller én, fire og ni måneder etter biopsitagningen.

\section{Pasient 3}

En jente i barneskolealder ble utredet på grunn av en diffus hevelse over høyre underkjeve. Bortsett fra residiverende ørebetennelser, hadde hun vært frisk. Hevelsen hadde kommet og gått periodevis i et års tid uten ledsagende symptomer. Pasienten hadde ikke hatt feber og var ikke blitt behandlet med antibiotika (figur 2).
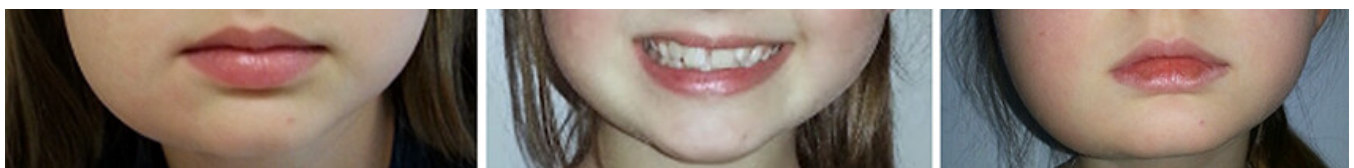

Figur 2 Pasient 3 ved kontroller med flere års mellomrom. Smerter og hevelse residiverer tidvis til tross for behandling med NSAID-preparater og steroider.

Ved klinisk undersøkelse observerte man asymmetri i ansiktet og en fast, lett palpasjonsøm hevelse på ca. $3 \mathrm{~cm}$ langs høyre underkjeve uten infeksjonstegn i huden eller tennene. MRog CT-undersøkelse viste ekspandert ben med ødem i høyre underkjeve og kontrastoppladning i omliggende bløtvev (figur 3).
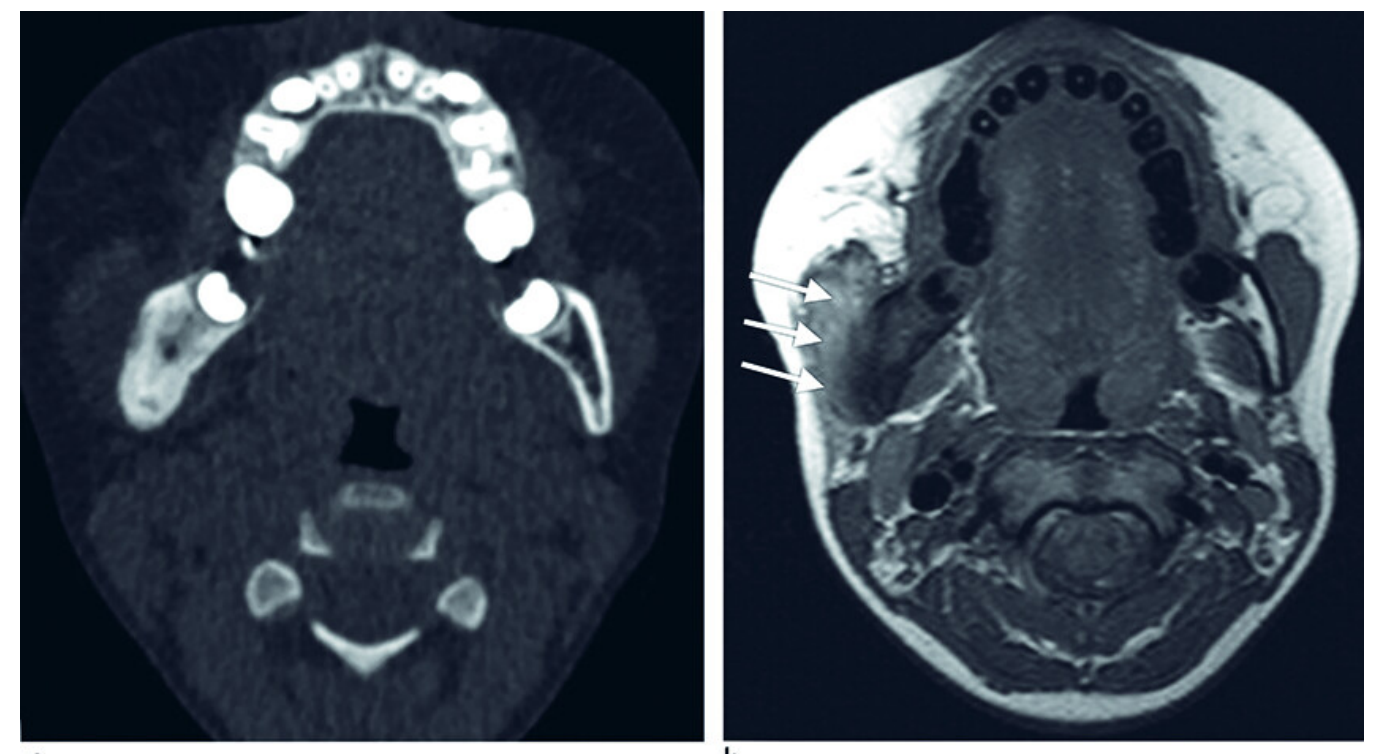

a

b

Figur 3 Pasient 3. a) CT (aksialt snitt) viser sklerotisering av benvev i ramus mandibula på høyre side og utvisket kortikal avgrensning. b) MR med kontrastvæske (aksialt snitt) viser inflammatoriske forandringer i omliggende bløtvev. Pilene viser oppdrevet musculus masseter på høyre side sammenlignet med kontralateral side.

Biopsi tatt under generell anestesi med intraoral tilgang viste bentrabekler omgitt av osteoblaster og noe bennydannelse, og noe inflammasjon med spredte lymfocytter, og ble tolket som kronisk osteomyelitt. Pasienten ble satt på behandling med

fenoksymetylpenicillin hos annen behandler (dose ukjent) i etterkant av biopsitagning. Dyrkning av den mikrobiologiske prøven ga oppvekst av Actinomyces oris og Staphylococcus aureus. 
På bakgrunn av resistensbestemmelse ble fenoksymetylpenicillin seponert til fordel for klindamycin peroralt $10 \mathrm{mg} / \mathrm{kg} \times 3$ i seks uker. Etter tre uker hadde hevelsen gått tilbake, og pasienten var tilnærmet symptomfri. MR med kontrast tre måneder etter biopsitagningen viste avtagende, men fremdeles tydelig reaksjon i underkjeven og omliggende vev. Etter ny dekortikering og biopsi uten funn av sekvestre, puss eller bakterieoppvekst ble behandling med klindamycin $10 \mathrm{mg} / \mathrm{kg} \times 3$ med planlagt varighet på seks måneder påbegynt.

Et halvt år senere avdekket ny MR-undersøkelse vedvarende inflammatorisk aktivitet i underkjeven. Antibiotikabehandling ble seponert ettersom pasienten var uten kliniske symptomer. En måned senere fikk pasienten på nytt trismus og hevelse samme sted. Ny biopsitagning viste ikke tegn til bakterier eller betennelsesceller. For å behandle eventuell infeksjon ble det startet behandling med nye antibiotikaregimer, også intravenøst, uten effekt på tilbakevendende episoder med smerter, hevelse og persisterende asymmetri i ansiktet. Antibiotikabehandlingen ble derfor seponert, og pasienten ble satt på fast behandling med NSAID-preparat (ibuprofen $200 \mathrm{mg} \times 2$ ). Dette hadde effekt, men symptomene blusset opp så fort ibuprofenbehandlingen ble seponert. Pasienten ble satt på fast behandling med ibuprofen $400 \mathrm{mg} \times 3$.

Syv år senere har pasienten fremdeles residiverende symptomer med hevelse og smerter fra kjeven. Hun bruker nå fast prednisolon $5 \mathrm{mg} \times 1$ og ibuprofen $400 \mathrm{mg} \times 1-3$ daglig samt omeprazol $20 \mathrm{mg} \times 1$. Ved gjennombruddssymptomer $\emptyset$ kes prednisolondosen til 10-40 mg. Hun vurderes for bisfosfonatbehandling.

\section{Pasient 4}

En gutt i barnehagealder ble innlagt med økende hevelse i venstre kinn, smerter og forhøyet CRP på $117 \mathrm{mg} / \mathrm{L}$. Han hadde forkjølelsessymptomer og sekresjon fra høyre øre. Gutten hadde hatt gjentatte ørebetennelser siden toårsalderen og fått innlagt dren i høyre $\emptyset$ re.

Intraoralt var det ingen tegn til fistler, infeksjon eller tannpatologi. CT-undersøkelse viste betydelig oppdriving i tyggemuskulatur, fortykket underkjeve og forstørrede lymfeknuter på venstre side, som radiologisk ble tolket som kronisk osteomyelitt.

Biopsi tatt med intraoral tilgang fra ramus mandibula under generell anestesi viste tegn til akutte betennelsesforandringer med infiltrat av nøytrofile granulocytter forenlig med osteomyelitt. Den bakteriologiske prøven viste oppvekst av streptokokker i mitis/oralisgruppen, grampositive kokker, Staphylococcus aureus, Actinomyces odontolyticus, Stomatococcus sp., apatogen Neisseria, Abiotrophia defectiva og Actinomyces.

Pasienten ble satt på behandling med høye doser penicillin $(75 \mathrm{mg} / \mathrm{kg} \times 4$ intravenøst $)$ i fire uker. Det ble deretter gjort kirurgisk debridering av kjeven. Peroperativt observerte man «morken» benoverflate, men ingen tegn til puss. Bensekvestre ble fjernet, og man kyretterte til friskt ben. Histologisk undersøkelse viste kronisk betennelse. Alle mikrobiologiske funn var en del av normal munnflora, og hadde således usikker klinisk relevans. Pasienten ble satt på behandling med cefotaksim $(50 \mathrm{mg} / \mathrm{kg} \times 4)$ og klindamycin $(10 \mathrm{mg} / \mathrm{kg} \times 4)$ intravenøst pga. resistensmønsteret av biopsimaterialet fra operasjonen, hvor de fleste bakteriene var resistente mot penicillin, men følsomme for klindamycin og kefalosporiner.

Pasienten ble fulgt med kontroller på kjevekirurgisk avdeling og ved barneklinikk. Antibiotikabehandling ble kontinuert med cefaleksin-mikstur i høy dose og klindamycinmikstur $(10 \mathrm{mg} / \mathrm{kg} \times 3)$ i tillegg til fast ibuprofen-mikstur $(15 \mathrm{mg} / \mathrm{kg} \times 3)$. Pasienten hadde varierende symptomer fra kjeven, og under forløpet ble kronisk ikke-bakteriell osteomyelitt mistenkt, og antibiotikabehandlingen seponert.

Noen måneder senere ble pasienten innlagt på nytt med hevelse i høyre overarm og abscesser på halsen. Etter omfattende utredning ble det påvist immunsvikt i form av kronisk granulomatøs sykdom. Pasienten ble stamcelletransplantert med påfølgende 
graftrejeksjon. Han ble deretter retransplantert og utviklet transplantat-mot-vert-sykdom. Pasienten døde fire år etter første utredning for osteomyelitt.

\section{Diskusjon}

Felles for de fire barna var at alle presenterte hevelse over underkjeven med varierende grad av smerte uten feber. Kjeveosteomyelitter er oftest assosiert med tanninfeksjoner, noe ingen av pasientene hadde. Likevel ble sykdomsbildene primært oppfattet som infeksiøse osteomyelitter og behandlet kirurgisk og med antibiotika.

Mikrobiologiske prøver ble i hovedsak tatt transoralt. I det ene tilfellet hvor man gjorde en transkutan, steril tilgang, fant man ingen bakterievekst. Mulig kontaminasjon fra munnhule og tidligere antibiotikabruk gjør at mikrobiologiske prøver tatt fra underkjeven må tolkes med varsomhet. Muligheten for ikke-bakteriell osteomyelitt ble vurdert sent, og hos enkelte av pasientene kunne man ikke være sikker på om dette var den primære diagnosen eller om tilstanden utviklet seg som reaksjon på en forutgående infeksjon. Pasient 1 hadde en typisk presentasjon av infeksiøs osteomyelitt, mens pasient 2 sannsynligvis hadde en selvbegrensende og immunindusert kronisk ikke-bakteriell osteomyelitt, som feilaktig ble behandlet med langvarig antibiotikakur. Forløpet hos pasient 3 tyder på en langvarig og residiverende kronisk ikke-bakteriell osteomyelitt. Pasient 4 hadde osteomyelitt med usikker patogenese som følge av underliggende sykdom.

Osteomyelittbegrepet benyttes tradisjonelt om en infeksiøs tilstand og deles gjerne inn i akutt og kronisk osteomyelitt. Den akutte varianten viser klare inflammasjonstegn med hevelse, puss og ofte fistler. Denne kan gå over i en mer kronisk fase med mindre dramatiske kliniske symptomer ((1,2), s. 56-65), men som også kan innbefatte puss og sekvestre.

Kronisk ikke-bakteriell osteomyelitt er en idiopatisk inflammatorisk tilstand. Den inflammatoriske forstyrrelsen skyldes trolig ubalansert cytokinuttrykk fra medfødte immunceller. Tilstanden beskrives derfor i nyere tid også som en autoinflammatorisk tilstand (3). Kronisk ikke-bakteriell osteomyelitt omfatter et vidt klinisk spektrum fra ganske milde, unifokale og tidsavgrensede beninflammasjoner til forlengede, multifokale, residiverende og noen ganger destruktive forløp. Den mest alvorlige presentasjonsformen kalles også kronisk residiverende multifokal osteomyelitt (1,3,4). Termen Garrès skleroserende osteomyelitt, som brukes av mange klinikere, betegner en lavgradig kjeveosteomyelitt med hittil antatt infeksiøst opphav, uten puss eller bendestruksjon, men med sklerosering og påleiring av ben. Tilstanden er også beskrevet som osteomyelitt med proliferativ periostitt. Patogenesen ved Garrès skleroserende osteomyelitt er dårlig definert, og sannsynligvis burde mange tilfeller vært diagnostisert som kronisk ikke-bakteriell osteomyelitt og behandlet deretter. Tabell 1 oppsummerer terminologien som i dag brukes i litteraturen om kjeveosteomyelitt.

\section{Tabell 1}

Terminologi brukt i litteraturen om bakterielle og ikke-bakterielle osteomyelitter i kjeveben. Fremstillingen er basert på forfatternes kjennskap til litteraturen og hvordan de ulike termene brukes i praksis.

\begin{tabular}{|lll|}
\hline Norsk term & Engelsk term (forkortelse) & Forklaring \\
\hline Bakteriell osteomyelitt & & \\
\hline Akutt osteomyelitt & Acute osteomyelitis (AO) & Bakteriell, mindre \\
& & enn fire uker med \\
& & kliniske \\
& & symptomer \\
\hline
\end{tabular}




\begin{tabular}{|c|c|c|}
\hline Norsk term & Engelsk term (forkortelse) & Forklaring \\
\hline Sekundær kronisk osteomyelitt & $\begin{array}{l}\text { Secondary chronic osteomyelitis } \\
\text { (SCO) }\end{array}$ & $\begin{array}{l}\text { Bakteriell, mer } \\
\text { enn fire uker med } \\
\text { kliniske } \\
\text { symptomer }\end{array}$ \\
\hline \multicolumn{3}{|l|}{ Ikke-bakteriell osteomyelitt } \\
\hline $\begin{array}{l}\text { Kronisk ikke-bakteriell osteomyelitt } \\
\text { / primær kronisk osteomyelitt }{ }^{1,2}\end{array}$ & $\begin{array}{l}\text { Chronic non-bacterial } \\
\text { osteomyelitis (CNO) / primary } \\
\text { chronic osteomyelitis (PCO) }\end{array}$ & $\begin{array}{l}\text { Idiopatisk } \\
\text { inflammatorisk } \\
\text { tilstand }\end{array}$ \\
\hline $\begin{array}{l}\text { Garrès skleroserende } \\
\text { osteomyelitt }^{1}\end{array}$ & Garrè's osteomyelitis & \\
\hline $\begin{array}{l}\text { Kronisk skleroserende } \\
\text { osteomyelitt }^{1}\end{array}$ & $\begin{array}{l}\text { Chronic sclerosing } \\
\text { osteomyelitis (CSO) }\end{array}$ & \\
\hline $\begin{array}{l}\text { Diffus skleroserende } \\
\text { osteomyelitt }^{2}\end{array}$ & $\begin{array}{l}\text { Diffuse sclerosing } \\
\text { osteomyelitis (DSO) }\end{array}$ & \\
\hline $\begin{array}{l}\text { Kronisk residiverende multifokal } \\
\text { osteomyelitt }\end{array}$ & $\begin{array}{l}\text { Chronic recurrent multifocal } \\
\text { osteomyelitis (CRMO) }\end{array}$ & $\begin{array}{l}\text { Multifokal kronisk } \\
\text { ikke-bakteriell } \\
\text { osteomyelitt }\end{array}$ \\
\hline Juvenil primær kronisk osteomyelitt & $\begin{array}{l}\text { Juvenile primary chronic } \\
\text { osteomyelitis (JPCO) }\end{array}$ & $\begin{array}{l}\text { Kronisk ikke- } \\
\text { bakteriell } \\
\text { osteomyelitt hos } \\
\text { barn og unge }\end{array}$ \\
\hline \multicolumn{3}{|l|}{ Assosierte tilstander } \\
\hline SAPHO-syndrom & SAPHO & $\begin{array}{l}\text { Synovitt, akne, } \\
\text { pustler, } \\
\text { hyperostose, } \\
\text { osteitt. Assosiert } \\
\text { med kronisk ikke- } \\
\text { bakteriell } \\
\text { osteomyelitt }\end{array}$ \\
\hline
\end{tabular}

${ }^{1}$ Termene brukes synonymt. Garrès skleroserende osteomyelitt / osteomyelitt med proliferativ periostitt og kronisk skleroserende osteomyelitt er betegnelser på osteomyelitt med ukjent etiologi, men som muligens er utløst av dentalt infeksiøst fokus. Disse tilstandene kan sannsynligvis også betegnes som kronisk ikke-bakteriell osteomyelitt.

${ }^{2}$ Diffus skleroserende ostemyelitt brukes oftest som en radiologisk betegnelse, beskrivende om kronisk ikke-bakteriell osteomyelitt.

Kronisk ikke-bakteriell osteomyelitt er assosiert med smerte, trismus, lymfadenopati og hevelse. Smertene kommer typisk i perioder, og er som regel nattlige og intense. Ofte ser man eksaserbasjoner og remisjoner over flere år (1 1), (5-7). . Det finnes ingen laboratorietest som er diagnostisk for tilstanden $(3, \underline{8})$, men røntgenbilder er ofte vesentlige for korrekt diagnostikk. Det er fravær av puss, fistler og bensekvestre. Tilstanden kan ramme barn, med typisk debut i alderen fra syv til tolv år, men kan forekomme i alle aldre (1,.9.), s. 161-5). Affeksjon av sternum er hyppigere hos voksne, mens clavicula og lange rørknokler er

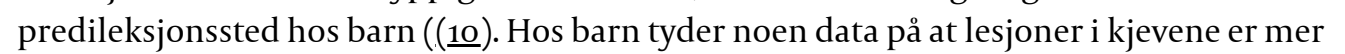
vanlig enn man tidligere har trodd. I en studie hadde $24 \%$ av barn med kronisk ikkebakteriell osteomyelitt lesjoner i underkjeven. 20 av 70 pasienter hadde unifokal sykdom, og hos disse var underkjeven den hyppigst affiserte knokkelen (12 pasienter) (1ㅡ). 
Kronisk ikke-bakteriell osteomyelitt i underkjeven har en rekke differensialdiagnoser: fibroossøse tilstander (f.eks. fibrøs dysplasi, Pagets sykdom, kjerubisme), benigne tumorer (f.eks. ossifiserende eller ikke-ossifiserende fibrom, sentralt kjempecellegranulom og odontogene tumorer) og maligne tilstander (f.eks. sarkom) (1, 12 $)$. For riktig diagnose er tidlig benbiopsi viktig. Aseptiske metoder er å foretrekke for å unngå feilaktig diagnostisering med infeksiøs etiologi (13). I kjeveregionen innebærer dette at man oftere bør vurdere en transkutan tilgang selv om det innebærer incisjon i hud og mulig arrdannelse for pasienten.

Uklarhet rundt osteomyelittbegrepet bidrar sannsynligvis til at både diagnostikk og behandling av kronisk ikke-bakteriell osteomyelitt i kjevene ikke er standardisert. Pasienter blir ofte først behandlet med antibiotika for antatt infeksiøs osteomyelitt og deretter med kirurgisk debridering. Det er grunn til å tro at flere osteomyelitter behandles unødvendig med antibiotika (13). Langtidsbehandling med antibiotika, som tradisjonelt er anbefalt ved osteomyelitt, kan forsinke korrekt diagnostisering, også fordi visse typer antibiotika har en antiinflammatorisk effekt.

Kronisk ikke-bakteriell osteomyelitt er fremdeles en eksklusjonsdiagnose der manglende effekt av antibiotika og fravær av infeksiøse mikrober peker mot diagnosen, underst $ø$ ttet av klinisk forløp og røntgenfunn. Tilstanden er sannsynligvis underdiagnostisert, og det er viktig å være oppmerksom på diagnosen tidlig i et sykdomsforløp. I de fleste tilfeller vil

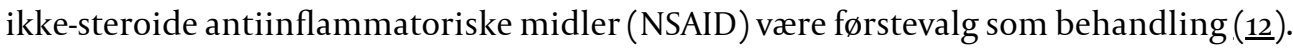
Bruk av benremodulerende medikamenter som bisfosfonater kan være et effektivt alternativ, særlig ved manglende effekt av NSAID-preparater $(\underline{8}, \underline{14})$.

Det bør etter vår oppfatning utarbeides klarere kriterier for å skille de bakterielle fra de ikke-bakterielle osteomyelittene, og dette bør gjenspeiles i terminologien. Ikke-bakterielle osteomyelitter er antakelig vanligere enn tidligere antatt også i kjevene (4). For å unngå misforståelser og forsinket behandling anbefaler vi at osteomyelitter alltid omtales som enten bakterielle eller ikke-bakterielle. For ikke-bakterielle osteomyelitter er kronisk ikkebakteriell osteomyelitt (på engelsk chronic non-bacterial osteomyelitis, CNO) sannsynligvis den mest anerkjente betegnelsen, og den bør være dekkende også for eventuelle undergrupper.

Selv om de fire tilfellene av osteomyelitt debuterte med likeartede symptomer, representerer de ulik etiologi og ulike behandlingsbehov. Pasientserien belyser således viktigheten av at hver pasient vurderes individuelt, og at tverrfaglig utredning og samarbeid ofte er nødvendig for riktig diagnose og behandling.

Alle pasienter og/eller pårørende har gitt samtykke til at artikkelen blir publisert.

Artikkelen er fagfellevurdert.

\section{REFERENCES}

1. Berglund C, Ekströmer K, Abtahi J. Primary chronic osteomyelitis of the jaws in children: an update on pathophysiology, radiological findings, treatment strategies, and prospective analysis of two cases. Case Rep Dent 2015; 2015: 152717. [PubMed][CrossRef] [Internet]. Available from: http://dx.doi.org/10.1155/2015/152717

2. Marx RE, Stern D. Oral and maxillofacial pathology. A rationale for diagnosis and treatment. 2. utg. Chicago: Quintessence Publishing Co, 2012.

3. Zhao DY, McCann L, Hahn G et al. Chronic nonbacterial osteomyelitis (CNO) and chronic recurrent multifocal osteomyelitis (CRMO). JTransl Autoimmun 2021; 4: 100095. [PubMed] [CrossRef] [Internet]. Available from: http://dx.doi.org/10.1016/j.jtauto.2021.100095

4. Schnabel A, Range U, Hahn G et al. Unexpectedly high incidences of chronic nonbacterial as compared to bacterial osteomyelitis in children. Rheumatol Int 2016; 36: 173745. [PubMed][CrossRef] [Internet]. Available from: http://dx.doi.org/10.1007/soo296-0163572-6

5. Monsour PA, Dalton JB. Chronic recurrent multifocal osteomyelitis involving the mandible: case reports and review of the literature. Dentomaxillofac Radiol 2010;39:184- 
9o. [PubMed]|CrossRef] [Internet]. Available from: http://dx.doi.org/10.1259/dmfr/2306o413

6. Girschick HJ, Huppertz HI, Harmsen D et al. Chronic recurrent multifocal osteomyelitis in children: diagnostic value of histopathology and microbial testing. Hum Pathol 1999; 30: 59-65. [PubMed][CrossRef] [Internet]. Available from: http://dx.doi.org/10.1016/Soo468177(99)90301-5

7. Theologie-Lygidakis N, Schoinohoriti O, Iatrou I. Surgical management of primary chronic osteomyelitis of the jaws in children: a prospective analysis of five cases and review of the literature. Oral Maxillofac Surg 2011; 15: 41-50. [PubMed][CrossRef] [Internet]. Available from: http://dx.doi.org/10.1007/s100o6-010-0248-3

8. Sælen AS, Madland TM, Løes S. Bisphosphonates in treatment of chronic aseptic sclerotizing osteomyelitis in the mandible. Scand J Rheumatol 2021; 50: 488-90. [PubMed] [CrossRef] [Internet]. Available from: http://dx.doi.org/10.108o/03009742.2021.1878275

9. Herlofson BB, Schiødt M, Wexell CL. Acute and chronic inflammation, osteomyelitis, medication-related osteonecrosis of the jaw and osteoradionecrosis. I: Bjørnland T, Nørholt SE, Rasmusson L et al., red. Nordic textbook of oral and maxillofacial surgery. København: Munksgaard, 2021.

10. Skrabl-Baumgartner A, Singer P, Greimel T et al. Chronic non-bacterial osteomyelitis: a comparative study between children and adults. Pediatr Rheumatol Online J 2019; 17: 49. [PubMed][CrossRef] [Internet]. Available from: http://dx.doi.org/10.1186/s12969-019-03532

11. Borzutzky A, Stern S, Reiff A et al. Pediatric chronic nonbacterial osteomyelitis. Pediatrics 2012; 130: e1190-7. [PubMed][CrossRef] [Internet]. Available from: http://dx.doi.org/10.1542/peds.2011-3788

12. Gaal A, Basiaga ML, Zhao Y et al. Pediatric chronic nonbacterial osteomyelitis of the mandible: Seattle Children's hospital 22-patient experience. Pediatr Rheumatol Online J 2020; 18: 4. [PubMed][CrossRef] [Internet]. Available from: http://dx.doi.org/10.1186/s12969-019-0384-8

13. Padwa BL, Dentino K, Robson CD et al. Pediatric Chronic Nonbacterial Osteomyelitis of the Jaw: Clinical, Radiographic, and Histopathologic Features. J Oral Maxillofac Surg 2016; 74: 2393-402. [PubMed][CrossRef] [Internet]. Available from: http://dx.doi.org/10.1016/j.joms.2016.05.021

14. Matharu J, Taylor H, Sproat C et al. Diffuse sclerosing osteomyelitis: a case series and literature review. Oral Surg Oral Med Oral Pathol Oral Radiol 2020; 129: 437-46. [PubMed] [CrossRef] [Internet]. Available from: http://dx.doi.org/10.1016/j.oooo.2019.11.010

Publisert: 14. februar 2022. Tidsskr Nor Legeforen. DOI: 10.4045/tidsskr.21.0478

Mottatt 4.6.2021, første revisjon innsendt 8.10.2021, godkjent 6.1.2022.

Publisert under åpen tilgang CC BY-ND. Lastet ned fra tidsskriftet.no 26. april 2023. 